\title{
Transnationalism of Burundian Refugees in The Netherlands: The Importance of Migration Motives
}

\author{
Peter Mascini, ${ }^{1}$ Alfons Fermin, ${ }^{2}$ and Hilde Snick ${ }^{3}$ \\ ${ }^{1}$ Faculty of Social Sciences, Erasmus University Rotterdam, Room M6-06, P.O. Box 1738, 3000 DR Rotterdam, The Netherlands \\ ${ }^{2}$ Erasmus University Rotterdam, 3000 DR Rotterdam, The Netherlands \\ ${ }^{3}$ University Asylum Fund, 3508 SK Utrecht, The Netherlands
}

Correspondence should be addressed to Peter Mascini, pmascini@gmail.com

Received 21 February 2012; Accepted 11 June 2012

Academic Editor: Shirlena Huang

Copyright ( $) 2012$ Peter Mascini et al. This is an open access article distributed under the Creative Commons Attribution License, which permits unrestricted use, distribution, and reproduction in any medium, provided the original work is properly cited.

It is equivocal whether the transnationalism of refugees differs significantly from that of labor and family migrants. On the basis of a strategic case study of Burundian refugees in The Netherlands we demonstrate that migration motives undeniably matter for transnationalism. Transnationalism is not self-evident for Burundians, as they are driven by a motive of flight. Moreover, transnationalism is not automatically oriented towards compatriots and manifests itself differently in The Netherlands than in Belgium. Therefore, we conclude that the study of refugees is an essential complement to the prevailing research on the transnationalism of settled labor and family migrant communities.

\section{Introduction}

Transnationalism has become an important field of research within migration studies since the 1990s. However, soon after the initial enthusiasm, skepticism followed: phenomena gathered under the denominator of transnationalism appeared to be anything but new, and the spread of these phenomena seemed largely overestimated. According to Portes [1, page 182] this overestimation was due to the fact that researchers investigated transnationalism in contexts renowned for it; in other words, the abundance of transnationalism was a direct consequence of how the dependent variable was selected. This bias emerged in at least three ways in studies on transnationalism.

Firstly, research was mainly carried out on transnationalism among settled migrant groups, first in the United States, and later also in other Western countries. Examples are Mexican migrants in the United States, Kurdish migrants in Sweden, and Indian migrants in the United Kingdom [2, 3], [4, pages 130-131]. Members of settled migrant groups can more or less automatically utilize networks of family, acquaintances, and transnational institutions for the arrangement of their voyage and stay in the country of destination, for developing transnational activities, and for arranging the eventual (temporary) return to the country of origin. Hence, transnationalism is easily available for members of settled migrant groups. However, this is not the case for members of "new" migrant groups and for dispersed migrant groups [5, page 880].

Secondly, much of the research on transnationalism selected respondents among members of associations and clubs in settlement countries with a clear predilection for the country of origin [3]. According to Jansen [6, page 185], this selective attention given by researchers to transnational institutions could explain why he did not find intensive transnationalism among Bosnian refugees, while other researchers did. Jansen came into contact with his respondents via personal networks, and not-as other researchers did-via refugee associations or clubs with strong ties to the country of origin.

Thirdly, most research on transnationalism addresses labor and family migrants. The question whether transnationalism takes on different shapes for these kinds of migrants in comparison with refugees who emigrated for political reasons has only sporadically drawn attention and has not yet been answered unequivocally. On one hand, some researchers state that refugees are less involved with transnationalism than labor and family migrants because 
migrants who have fled large-scale violence attempt to avoid involvement with the country of origin [5, page 879] or will limit their transnational activities to political resistance against the system from which they have fled [7, pages 150154]. On the other hand, others maintain that refugees do not differ as remarkably from labor and family migrants regarding their social, cultural, and economic transnational activities as is generally assumed [8,9], although Bloch [9] also finds that refugees are politically more active transnationally than other types of migrants. Hence, it is disputed whether or not transnationalism of refugees differs fundamentally from that of labor and family migrants.

Our aim is to examine the significance of migration motive for the transnationalism of Burundian asylum seekers who have not had much time to settle as a migrant community in The Netherlands. Our central research question is as follows: how do migration motive and country of settlement affect the nature and extent of transnational activities and orientations among Burundian refugees? We will explore whether or not the three assumptions dominating the start of the "transnational turn" in the 1980 s-that transnationalism is more or less self-evident; that this is connected with the "natural" bond between fellow countrymen; and that countries of settlement are interchangeable in relation to transnationalism-also pertain to Burundians who have settled in The Netherlands. We have chosen to study this particular migrant population because it differs in all respects from those studies criticized by Portes for their bias in the selection of the dependent variable. Namely, the migration population we studied differs in the extent to which it is settled, its members' motives for migration, and the institutional embeddedness of its members. Burundians in The Netherlands constitute a small community, consisting mainly of asylum seekers who have arrived fairly recently. Hence, this is not a study of a settled community of labor and family migrants. Moreover, the study is not limited to members of Burundian organizations and associations, but covers the transnational contacts and orientations of Burundian asylum seekers with various socioeconomic backgrounds. (Finally, our analysis is limited to the transnationalism of Burundians in the country of settlement of The Netherlands; we have not done research on the transnationalism of Burundians outside The Netherlands.)

\section{Data Collection}

Data has been collected by the third author [10]. She started the selection of respondents with the snowball sampling method. Initially, four key persons brought her into contact with other Burundian migrants in their networks. This strategy was supplemented with other methods in order to prevent respondents being solely recruited from the upper class of the Burundian migrant community. These methods included Snick approaching Kirundi speaking people, addressing the public and artists during a Burundian drummers' concert, establishing contact with Burundians with various residence permits with the assistance of the Dutch Refugee Council (Vluchtelingenwerk Nederland), and looking up Burundian last names in the phonebook. (Snick used the phonebook listed on the website of a Dutch national telephone company (http://www.detelefoongids.nl/, similar to any national White Pages phonebook) and typed typical Burundian last names in the category "Who." While selecting among the hits the search provided the author for optimal geographic dispersion of respondents across all regions in The Netherlands).

In total, eighteen Burundian refugees residing throughout The Netherlands were interviewed. The interviews were semistructured, using a topic list with the main theme being respondents' contact with Burundian people in The Netherlands, in Burundi, and elsewhere. Each interview lasted approximately one hour. Respondents were mainly interviewed in French, except in some cases where the respondent mastered the Dutch language. The selection of respondents consisted of twelve men and six women. Their age varied between twenty and fifty years. Although the most deprived migrant category-unskilled or illegal migrantsis missing, the selection does contain low-skilled Burundians with unfavorable socioeconomic positions (see Table 1). Nine respondents had a temporary residence permit, eight had a Dutch passport, and one respondent was still waiting to hear about her asylum application from the Immigration and Naturalization Service (IND). Six respondents had stopped going to school while in Burundi, eight had finished primary or secondary education, and six had finished some form of higher education or university. Eleven respondents had not been working at the time they left Burundi, four had been employed in low paid jobs and three respondents had been in well-paid jobs for the Burundian government. At the time of data collection in The Netherlands, six respondents did not have a paid job, seven had a temporary job, and five had a permanent job.

\section{Background of Emigration from Burundi}

To place our analysis in context, we first outline both the turbulent political history of Burundi and then the history of migration from Burundi to The Netherlands.

The Republic of Burundi is located in the Great Lakes region of eastern Africa. In comparison to other African countries, Burundi has a rather homogeneous population consisting of Hutus, Tutsis, and Twa. These three categories share the Rundi culture and Kirundi as a common language. For this reason some researchers consider the inhabitants of Burundi a single ethnic group $[11,12]$.

Burundi was originally established as a kingdom in the sixteenth century [13]. Subsequently, at the Berlin Conference of 1884-1885, at which Africa was divided between the main European powers, the area of Burundi was part of the territory allocated to Germany. After the First World War, Burundi became part of the Belgian colonial empire. The Belgians cultivated the myth of Tutsis as predestined to rule over Hutus and dismantled the complex social structure characterized by intricate interdependencies between both categories. The fluidity once characteristic of the Hutu and Tutsi status was replaced by a rigid conception of identity in terms of ethnic primordialism [14] emphasizing the unequal relationship between both categories [13]. 
TABLE 1: Background characteristics respondents.

\begin{tabular}{|c|c|c|c|c|c|c|}
\hline & Pseudonym & Age & Marital status & Residence status & Education before emigration & Education in The Netherlands \\
\hline (1) & Monique & 36 & Divorced & Naturalized & University (stopped) & Higher professional education (stopped) \\
\hline (2) & Pierre & 26 & Single & For 5 Years & University (stopped) & Higher professional education (in progress) \\
\hline (3) & Viviane & 50 & Married & Naturalized & $\begin{array}{l}\text { Higher professional education } \\
\text { (completed) }\end{array}$ & Dutch as a second language \\
\hline (4) & Marcel & 22 & Single & For 5 Years & Secondary school (completed) & Higher professional education (in progress) \\
\hline (5) & Véronique & 20 & Single & $\mathrm{W}$-document ${ }^{1}$ & Secondary school (completed) & Secondary vocational education (in progress) \\
\hline (6) & Lucien & 47 & Married & Naturalized & $\begin{array}{l}\text { Higher professional education } \\
\text { (completed) }\end{array}$ & Dutch as a second language \\
\hline (7) & Patrick & 32 & Married & Naturalized & University (stopped) & University (completed) \\
\hline (8) & Emile & 36 & Single & For 5 Years & $\begin{array}{l}\text { University (finished in another } \\
\text { African country) }\end{array}$ & Higher professional education (in progress) \\
\hline (9) & Philipe & 41 & Divorced & Naturalized & $\begin{array}{l}\text { Higher professional education } \\
\text { (completed) }\end{array}$ & Dutch as a second language \\
\hline$(10)$ & Leon & 33 & Married & For 5 Years & University (stopped) & Higher professional education (in progress) \\
\hline$(11)$ & Stéphane & 27 & Single & For 5 Years & Secondary school (completed) & Dutch as a second language \\
\hline$(12)$ & Bernard & 37 & Divorced & For 5 Years & $\begin{array}{l}\text { Secondary vocational education } \\
\text { (completed) }\end{array}$ & Dutch as a second language \\
\hline$(13)$ & Valère & 27 & Single & For 5 Years & $\begin{array}{l}\text { Secondary vocational education } \\
\text { (finished in another African country) }\end{array}$ & Secondary vocational education (in progress) \\
\hline$(14)$ & Alice & 23 & Single & For 5 Years & Secondary education (in progress) & Dutch as a second language \\
\hline$(15)$ & Claudine & 28 & Married & For 5 Years & University (stopped) & Higher professional education (in progress) \\
\hline$(16)$ & André & 25 & Divorced & For 5 Years & Primary education (completed) & Secondary vocational education (in progress) \\
\hline$(17)$ & Maurice & 48 & Single & Naturalized & University (completed) & Dutch as a second language \\
\hline$(18)$ & Isabelle & 36 & Married & For 5 Years & $\begin{array}{l}\text { Higher professional education } \\
\text { (completed) }\end{array}$ & Dutch as a second language \\
\hline
\end{tabular}

${ }^{1}$ Document for asylum seekers whose application is still in progress.

Following Burundi's independence in 1962, the political situation was unstable. A first wave of large-scale violence took place in 1965, after a Hutu prime minister was assassinated. Militant Hutus established a liberation movement in the neighboring countries. In 1972, they attacked major cities in Burundi; the fighting and its aftermath resulted in more than 200,000 casualties. In 1988, Hutus killed hundreds of Tutsis during riots. In response, the army killed roughly 20,000 people, while tens of thousands Burundians fled their homes. The assassination of the first Hutu head of state by Tutsi soldiers during a coup after the first free elections of 1993 resulted in further violence and bloodshed between Hutu extremists and the Tutsi army [13, page 5]. Tens of thousands of people were killed within a matter of days. In 1994, the newly elected president of Burundi and the president of Rwanda died when the airplane they were traveling in was shot down. This incident was the immediate cause of the Rwandan genocide. The country was ethnically divided; killings continued with many citizens as both perpetrators and victims [15]. Out of a population of eight million, one million Burundians were displaced or forced to flee. Peace talks between stakeholders started as a result of international pressure and in 2000, a peace agreement was signed by the president and most armed factions. With the help of a UN mission in Burundi the treaty still endures; however, the political situation remains unstable and the population continues to suffer from armed attacks.

Civil war, oppressive politics, and genocide have periodically forced large numbers of Burundi's population to leave the country and go into exile [15]. For example, at the end of 2006, Burundi remained one of the main-source countries of refugees-approximately 400,000 refugees were recognized as such according to the Geneva Conventionbut, at the same time, Burundi has experienced major flows of returnees [16]. Most refugees remained in exile in neighboring countries, particularly Tanzania. In 2012, there are still some 150,000 internally displaced persons living in settlements in Burundi as well as some 90,000 refugees and asylum seekers originating from Burundi [17].

Refugee flows to The Netherlands began in 1993. From 1993 to 2008, 3,344 Burundians applied for asylum in The Netherlands. (The figures for 1993 to 2004 are based on the Migration Policy Institute [18] data online; consulted in June 2009. Data for 2005 and 2006 are based on De Boom et al. [19]; data for 2007 and 2008 are based on figures from [20] online database Statline; consulted in June 2009.) Up until 2006, all Burundian asylum seekers were given at least a temporary residence permit on humanitarian grounds, based on Dutch immigration policy for specific countries. In other words, the Dutch government perceived the situation in Burundi to be too dangerous to return asylum seekers to 
their country of origin. In 2006, this categorical protection policy was dismantled and the temporary residence permits were withdrawn. (Between 2005 and 2008, 1.570 residence permits have been granted to Burundians, of which 640 for an undetermined amount of time. ([20], consulted in June 2009).)

\section{Transnationalism of Burundian Refugees}

Hence, the small community of Burundian refugees that has recently settled in The Netherlands deviates essentially from the settled labor and family migrant communities known for their active transnationalism. Does this imply transnationalism is not self-evident for our respondents; do they not automatically identify with compatriots, and do they attach a different meaning to The Netherlands as a settlement country than to Belgium as the former colonizer of Burundi?

\section{Nature and Extent of Transnationalism}

Before we answer the question of the nature and extent of transnationalism among our selection of Burundian respondents we first clarify how we use this concept in our analysis. In general, transnationalism refers to the situation in which migrants are simultaneously embedded in the societies of more than one nation state [4, page 131]. Formulated differently, transnationalism refers to a situation in which migrants are embedded in "networks linking people in sending and receiving nation states who by cross border connections create new transnational spaces" [21, page 4]. These "transnational social spaces" not only encompass the countries of origin and settlement, but also other locations in the world where fellow countrymen live with whom migrants keep in touch, the so-called diaspora. As already mentioned, our analysis is limited to the microlevel of individual migrants; hence we set aside both the mesolevel of transnational institutions and the macro level of the policies of sending and receiving countries. We understand the transnational embeddedness of individual migrants in societies of two or more countries both in terms of "ways of being" - that is, the actual social relations and practices that are part of the life of migrants - and in terms of "ways of belonging" — that is, practices expressing a feeling of belonging to or identification with a specific group or location [22].

Our broad interpretation of this definition of transnationalism at the level of individual migrants is evident in three respects. Firstly, in our conceptualization, transnationalism consists not only of physical geographical mobility, but also of the exchange of material sources, information, and ideas across borders. Secondly, we do not limit the definition of transnationalism to structural, permanent forms of transnational practices and orientations; we include incidental, temporary practices, and orientations as well. Thirdly, we also account for the mutual interactions between Burundians in The Netherlands when analyzing transnationalism. In a strict sense, these contacts fall outside the scope of our definition of transnationalism because they are not border-crossing practices. However, we have included these interactions in our analysis because they proved to be of indirect importance for the transnational involvement of our respondents. Mutual interaction between Burundians in The Netherlands led to an exchange of information about Burundi and those who stayed behind [8], [9, page 301]. As Carling [23, page 1455] states, the analysis of transnational practices and their impact should include not only people actually engaged in transnational practices, but also those who are part of the social constellation connected by transnational relationships. Furthermore, the way in which respondents interacted with their fellow countrymen in The Netherlands more or less reflected their interactions with fellow countrymen in the diaspora and in the country of origin. In short, we label some practices and orientations as transnational that would otherwise fall outside the scope of a narrower definition of transnationalism. We have consciously opted for a broad definition so that we could grasp differences in transnationalism between respondents that would otherwise have remained invisible if we had chosen to maintain a narrow definition. Moreover, these differences were significant for the respondents themselves.

According to our definition of transnationalism, most Burundians included in our study were somehow transnationally active. Fourteen of the eighteen respondents maintained relationships with fellow countrymen in Burundi and fifteen respondents maintained contact with Burundians in the diaspora. The latter predominantly concerned relationships with compatriots in Belgium or people they had met in the United Nations' refugee camps where respondents had lived before they were invited to come to The Netherlands under refugee status. Most interactions did not take place physically, but by (mobile) phone, internet forums, mail, fax, or money remittances. Additionally, our respondents visited fellow countrymen in Belgium and Burundi.

Most of the contacts were socially oriented and involved family and friends. Furthermore, respondents also mentioned religious contacts with people of the same faith; cultural contacts, particularly associated with the most wellknown cultural exponent of Burundi, the Tambourinaires de Burundi; sporting interactions, in particular table tennis and soccer competitions between Burundian teams from The Netherlands and Belgium; economic relationships maintained predominantly through aid development projects; political contacts. Moreover, all respondents kept in touch with fellow countrymen in The Netherlands. These contacts consisted of informal conversations, friendly visits, praying together and joint visits to political or cultural activities. Contacts with Burundians in The Netherlands usually did not consist of people the respondents had known in Burundi, but people they had met in The Netherlands, often in centers housing asylum seekers.

Though the majority of the respondents were transnationally active in some way or another, this was not the case for all respondents. For example, six respondents did not maintain contact with family in Burundi because they did not know where their family members resided or because they no longer had any family living in Burundi. Moreover, communication was often inconsistent, limited to irregular contacts by phone or to visits to Burundian internet forums hosted from Belgium, France, Canada, or The Netherlands. 
Transnationalism was difficult for different reasons. First, it was often technically impossible to keep in touch with family outside Burundi's capital because (mobile) phones and internet were not widely dispersed. As a result of few or slow internet connections, most transnational contacts via internet took place between compatriots within the diaspora. Stéphane (male, age 27, temporary residence permit) explained how difficult it was to phone his mother. When he wanted to talk to his mother, he would phone her neighbors. They subsequently made an appointment for a number of days later and made sure that his mother would be with the neighbors at the appointed day and time. If his mother wanted to talk to him, she would warn a friend of Stéphane, who would subsequently call Stéphane, who would then phone the neighbors at the agreed moment when his mother would be present.

Residence permits could pose another problem for transnational practices. Asylum seekers whose request for asylum was still being processed or who had received a temporary residence permit were not allowed to travel to Burundi; doing so meant losing the rights attached to their current asylum status. Other respondents avoided contact with fellow countrymen because they considered such contact a hindrance to their goal of passing the civic integration examination in The Netherlands. They were afraid these contacts would take place at the expense of their orientation towards The Netherlands and the Dutch people: "In that case, your language does not progress." All respondents took the civic integration exam seriously because passing it was a precondition for obtaining a Dutch passport. Furthermore, a number of respondents pointed out that they were too busy to maintain contacts with fellow countrymen:

"I want to achieve level two [of the Dutch language examination]. I do my homework every day. Often I have no time to make a phone call. When I am called by Burundians I know, I want them to get to the point. Talking on the phone for five minutes is long enough" (Isabelle, female, age 36, temporary residence permit).

Transnational interactions was also difficult for respondents lacking economic and social capital. Not all respondents could afford to phone, travel or send money to those who stayed behind. For example, Monique (woman, 36 years old, naturalized) lived in difficult financial conditions ever since her father was killed in 1972. She heard from others who had visited Burundi that her mother lived in poverty. She sent money to her mother that she did not have herself: "Being financially in the hole helps a little bit." Others were impeded by the insecurity associated with their temporary residence permit or they lacked the indispensable social contacts to start a project in Burundi. Stéphane (male, age 27 , temporary residence permit) discontinued the vocational education he needed to start a computer project in Burundi. He said "Perhaps it is because of the uncertainty of whether or not they will allow me to stay long enough to finish my education and get a degree." He remarked on his limited social capital:

\begin{abstract}
"There are a lot of Burundian executives in The Netherlands, Belgium, France and Canada: all sorts of people, ranging from ministers to professors. It seems as though only the president does not live abroad. But I do not know anybody, I have no way in. I am unfamiliar with donor organizations and I do not know how to write a project proposal."
\end{abstract}

However, transnationalism was not only absent for practical reasons. Some respondents deliberately renounced transnational activities. They were afraid this would cause them trouble again. For example, Marcel (male, age 22, temporary residence permit) went to live with his uncle and aunt in Bujumbura after his parents had died in the war. After his uncle disappeared without a trace, he fled the country with the help of a family friend. He talked about contact with fellow Burundians in The Netherlands as follows: "It is not good to have contact. Sometimes it scares me because when I call my aunt in Bujumbura she always tells me to 'watch out and be careful." Bernard (male, age 37, temporary residence permit) managed to escape from prison-where he had been locked up for a year-during an attack by a group of rebels. He had only superficial contact with fellow countrymen in The Netherlands. He said "I am not in Burundi. I'm in Europe. The community, the drummers, that does not interest me. It's better to avoid them; otherwise you can get into trouble."

\section{Two Categories: Transnationalism as Possibility and Choice}

Among the respondents, two categories could be distinguished that clearly differed with regard to the extent to which they were able and willing to maintain transnational contacts.

The first category consisted of Burundians who had previously stayed in Europe for study or work by the time the situation in Burundi escalated during the 1990s, or those who were quickly recognized as refugees because they could prove they were persecuted by Burundi rulers because of their publicly visible political activism. These Burundians had the means and the connections to flee the country quickly. They left before the ethnic conflict escalated and did not experience the war personally. Therefore they were uninhibited in their contact with the country of origin. Moreover, most of these respondents possessed a Dutch passport that allowed them to travel to and from Burundi and they could afford to pay for these travels as well. Not only did they maintain social contacts with people in Burundi, they were also involved in sociocultural and political institutions and organizations in The Netherlands, and with the help of development aid they participated in development activities in Burundi [24, 25]. A good example of respondents in this category is Maurice (male, age 48, naturalized). He is highly qualified and manages a successful micro credit project for farmers in the Burundian countryside. He works part-time as an accountant and part-time on his project. He owns a house in the capital and travels there once or twice a month. He plans to work full-time on his project 
from The Netherlands. All project plans he has submitted thus far have been subsidized by Belgian and Dutch donors. Moreover, Maurice is a member of a Burundian cooperation located in Europe that was established in Belgium, and he created a platform intended to improve collaboration between Burundian organizations active in The Netherlands. The other five respondents involved in development projects in Burundi also had the right contacts to get a project started in bureaucratic Burundi and they knew the right channels in The Netherlands to obtain funding for their projects.

The second category consisted of respondents who had fled after the ethnic conflict had escalated in 1993 and had experienced these conflicts personally. Some of them had sheltered in protected refugee camps of the United Nations in surrounding countries and had been invited by the Dutch authorities to apply for asylum. These people maintained little contact with Burundi because they had hardly any family left there, or because their past was so emotionally charged that they neither could nor wanted to go back. Transnational contacts with fellow Burundians were often limited to the people with whom they had spent time in a refugee camp. Others had fled the country on their own and had requested asylum upon arrival. These were mainly young men with a temporary residence permit, who had not been able to flee the conflicts in time and who had experienced the war personally. If they would return to Burundi, they would lose their right to asylum. These men developed a weak transnationalism: now and then they called the country of origin or remitted money home. They maintained relations with Burundians they had met in the asylum seeker center they had stayed in. Not only was the category of Burundians that had fled the country as a direct consequence of the fighting reticent towards contacts with other Burundians here and elsewhere, they also had less social and cultural capital to maintain contacts with Burundi and they usually had no Dutch passport allowing them to travel to Burundi.

In short: the Burundians that had been the in The Netherlands longest, maintained the most intensive transnational contacts because they wanted to and had the means to do so. The respondents who had fled after the ethnic conflicts had escalated were less inclined to maintain such contacts due to their fear to get drawn into the conflict again and lacked the necessary economic and social capital and the residence permit to do so. In other words, the Burundians who had arrived before the conflicts erupted in 1993 were transnationally more active than those who arrived thereafter. For similar reasons, Al-Ali et al. [26, pages 587, 597] found more transnationalism amongst Eritrean migrants who had fled during the independence war-between 1961 and 1991-than amongst Eritreans who had fled after the conflicts with Ethiopia had flared up at the beginning of the twentieth century. (Hence, the rapid intergenerational decline of transnationalism does not automatically imply a linear evolution [21].) Comparable differences of the extent to what asylum seekers have the capability and the willingness to be transnational are found among Eritrean, Albanian Yugoslavians, and Bosnians [8, 27]. For instance, Bosnian Muslims who were granted political asylum in The Netherlands or the United Kingdom experienced much more opposition in their attempts to maintain social contacts with compatriots that remained in the territory under Serbian government than those with relations in Bosnia-Herzegovina where Bosnian Muslims were in power. And Eritrean asylum seekers who disapproved of the Eritrean government were more reluctant to pay a voluntary tax for the reconstruction and independence to the Eritrean government than supporters of the government [8, page 630].

This leads to the conclusion that the capability of transnationalism cannot be assumed readily available for refugees, because they often lack the necessary economic and social capital, and permanent residence permit [28], [26, page 588], [29, page 785], [7, page 149], [5, page 887]. Neither can their readiness for transnationalism be assumed present as a result of their fear to get drawn into conflicts again they have fled from before [30, pages 870,872$]$. This means transnationalism of refugees is not self-evident and endorses the importance of migration motive in relation to transnationalism.

\section{Migrant Communities Are Not Homogeneous: Consequences for Transnationalism}

Not only is transnationalism occasionally assumed to be self-evident, but migrants originating from one country are often represented as a homogeneous group in the country of settlement as well [31], [26, page 594], and [4, page 144]. According to Lucassen [21], the public and the politicians of receiving countries often suppose an automatic solidarity between immigrants originating from the same country. Consequently, no distinction is made in their involvement with their country of origin. Authorities of sending countries like Mexico, Morocco, and Turkey contribute to this image of homogeneous migrant populations because they boost the "natural" link between emigrants and their country of origin in their emigration policy and attempt to stimulate the continuation of this link through all sorts of measures [32]. Surveys also often assume a rather uniform image of migrant populations [28, page 30]. Migrants are classified according to their nationality or country of origin and general conclusions are drawn, such as: "Moroccans are less involved in transnational activities" [33, page 294]; see also $[5,29]$.

"Being Burundian" was indeed an important identity marker for the respondents in the present study. Despite the ethnic division in the country of origin, they called themselves Burundian rather than Hutu or Tutsi. Moreover, most respondents said that Hutus and Tutsis live together peacefully in The Netherlands and that almost all activities were organized for both groups. Additionally, most respondents said they wanted to reconcile with each other and that the ethnic divisions in their country of origin were politically constructed and had not always existed. Philip (male, 41 years old, naturalized) remarked "Burundians are brothers. The Burundian conflict has been used as an instrument to hold on to power. But in Burundi, in the church, at the market, on the soccer field, on the "collines", Burundians 
walk hand in hand everywhere." Turner [34, page 1165] also states that the Burundian conflict can no longer be solely understood in terms of ethnic contrasts: "In brief, Burundi has experienced a shift from binary conflict between two irreconcilable positions based on ethnicity-two positions that could not even agree on what the conflict was about (Lemarchand, 1996) - to a complex conflict between a multiplicity of opinions and alliances where ethnicity no longer is the main fault line."

Yet ethnic contrasts slumbered beneath the surface. The first sign of this was evident from the fact that most respondents agreed to be interviewed under the condition that they would not be questioned about political and ethnic contrasts in their country of origin. Although this subject was therefore not raised as a separate interview topic, it was frequently brought up by respondents themselves. Marcel (male, age 22, temporary residence permit) said: "You almost forget the Hutu-Tutsi matter. You even do not want to talk about it anymore. We try to be Burundian, but you are aware of what has happened anyhow." Many young Burundians who were raised with the conflicts in Burundi had adopted the ethnic rhetoric of the political parties, including the resentments towards members of the other ethnic group. Irreconcilable viewpoints regarding the Burundian question were predominantly brought up by these respondents. André (male, age 25, temporary residence permit) is a Tutsi whose father was killed. He said he did not know where his mother and sisters were. Regarding his time spent at the refugee camp, he said the following:

"You couldn't talk to anybody. You even couldn't trust Burundians. Some of them did things that were wrong. Some have a bad past. There are also racists. If you tell them your story.... It's not good."

He had no contact with other Burundians in the place where he lived. He lived with a Congolese Tutsi he had met in the refugee camp:

"We speak the same language, we share the same ethnicity, that's why he is my friend. There is another Burundian living in the neighborhood, but he is a Hutu. And given what has happened in the past, it is difficult for me to associate with him."

Others avoided Burundian politics and politicians because they held them accountable for the conflicts that had disrupted their country. Pierre (male, age 26, temporary residence permit) said "I do not like politics. My father was never involved in politics and yet they killed him just like that." Therefore, he separated himself from local members of Burundian political parties: "You try to avoid these people. I do not even want to know them." In short: there was a simultaneous orientation towards a shared national origin as well as a (latent) experienced political and ethnical contrast concerning the country of origin that made some respondents decide not to make contact with fellow countrymen.

On other hand, there were respondents who declared they wanted to work towards reconciliation. However, they did not want reconciliation based on a shared nationality, but on a shared religious conviction. Among the respondents, fifteen were religious: six Catholics, four Protestants, four Catholics who converted to Protestantism in The Netherlands, and one Muslim. Half of the respondents attended church services weekly. About a third of the religious respondents chose a church in the neighborhood where they were often the only Africans present. Another third of them purposely avoided professing their faith in churches that were popular among compatriots. The others deliberately chose to visit churches where other Africans congregated, including people from Burundi, Congo and Rwanda. Pierre (male, age 26 , temporary residence permit) had started a prayer group at the asylum center he lived in, consisting of 120 members. He said the group tried to start a dialogue. Politics were not discussed, but the necessity of living together peacefully and the necessity of reconciliation was preached. Sometimes, a priest from a country other than Burundi or Rwanda was invited: According to Pierre, "With someone like that, the message comes across better because he is not part of the problem." Hence, it was not a shared nationality, but rather a shared religious faith that some respondents used to overcome the ethnic divisions resulting from Burundi's turbulent history.

In sum, contact and identification with fellow countrymen in The Netherlands was not self-evident given the smoldering ethnical and political opposition among Burundians. This heterogeneity among Burundians in The Netherlands manifested itself in mutually exclusive networks and in hybrid identities. However, these differences between compatriots with different ethnic and political backgrounds were sometimes overcome through a shared religious faith. The heterogeneity that originated from the situation in Burundi also determined respondents' transnational involvement with Burundi.

Therefore, on one hand it cannot be assumed that a shared national origin is associated with feelings of solidarity among Burundians. This conclusion counters Schuster's [35] argument that currently there is no reason for migrants to forget about their home country or to ignore the past. On the other hand, this does not mean that transnational identification with fellow countrymen can be ruled out a priori if political and ethnic conflicts have been the most important motive for migration. After all, a common religious belief was employed to at least temporarily bridge differences resulting from conflict in the country of origin [4, page 144].

These findings point first and foremost to the importance of the distinction between migrants who are selective or not in their contacts with compatriots [28, page 21], $[8,26]$. Previous research has established that political divisions and alliances can obstruct the solidarity between labor and family migrants coming from the same country of origin. For instance, conflicting identities in Bengali speaking families in Singapore such as Indians versus Bangladeshi, Hindus versus Muslims, secular individuals versus religious individuals, and nationalists versus cosmopolitans hampered mutual contacts within this seemingly uniform community [36]. However, it is even more likely that differences, divisionary lines, and 
mistrust shape transnationalism in the case of refugees: "If community can be questioned for ethnic minorities, it must be examined even more carefully when considering refugees, whose experiences in the conflict that they have sought refugee from may mean that there is no political unity and there may be strong differences within the group" [37, page 41]; see also [38, page 234]. Again, these insights endorse the conclusion that the motive for migration is important in relation to transnationalism.

Furthermore, we have shown that transnational involvement also occurred among migrants who shared other features than national origin [39, page 1189]. For example, we saw that migrants from African countries other than Burundi participated in evangelic communities in which Burundian Christians also participated, and that these religious communities were also transnationally active, such as inviting a pastor from another African country to participate. Other research has shown that Bosnian Muslim organizations maintained intense links with general Muslim organizations [6, page 624]. Another study demonstrated that second generation Hindu-Surinamese living in The Netherlands are more oriented towards India and Indian people than towards Surinam, partly a result of the influence of Bollywood culture [40]. This orientation can even result in contact with Indians living elsewhere as well as visits to these countries. There is a greater chance that transnationalism will be relatively detached from the shared national origin when there is evidence of ambivalence towards compatriots. The likelihood of ambivalent feelings towards compatriots is greater among refugees than among labor and family migrants because of the conflicts that induced their flight. This is the third indication that migration motives are important in explaining transnationalism.

Finally, our findings show that transnationalism is a dynamic process.

Transnationalism is not a "state of being," [...] but rather [...] a dynamic process [6, page 615]; see also [41, page 6], [42, page 139]. With the passage of time, the aversion towards being in contact with Burundian compatriots who were seen to be perpetrators of injustices in Burundi was sometimes bridged through a shared religious faith. However, this willingness to reconcile could disappear should conflict break out again in Burundi. Al-Ali et al. [8] found a comparable dynamic among Bosnian and Eritrean asylum seekers. While transnationalism predominantly consisted of political opposition against governors of their country of origin during the conflict, transnationalism was displaced to social, economic, and cultural activities after the conflicts had ended and the prospect of repatriation had faded to the background. In other words, the significance of migration motives for explaining transnationalism can change.

\section{Diaspora Is Not Homogeneous: The Importance of the Country of Settlement for Transnationalism}

A third assumption about transnationalism pertains to the diaspora. According to Sheffer [43], this term was originally used to describe specifically the coerced dispersion of Jews,
Greeks, and Armenians across various destinations. But this term has now obtained a much broader definition. Currently, the diaspora signifies a common origin, the maintenance of regular contacts with the area of origin, and transnational networks. Faist [44, page 16] argues that both transnational migrant populations as well as the diaspora are wrongly considered to be a homogeneous unit. This assumption occurs mostly in The discourse on the use of "the" migrant community to assist development in the country of origin, a popular topic embraced by NGOs $[42,45-48]$ as well as researchers $[49,50]$.

However, our respondents perceived transnationalism to be different depending upon the country of settlement (regarding the heterogeneity of the Burundian diaspora, see also [34, page 1164/5]). Burundian migration populations in Belgium and The Netherlands proved to be fundamentally different. The migration of Burundians to The Netherlands predominantly gained momentum as a result of the war that occurred during the 1990s. However, students and refugees had already been immigrating to Belgium since independence in 1962. This migration flow undoubtedly had to do with the fact that Belgium, under mandate of the former League of Nations, governed Burundi in the period between the First World War and independence in 1962. Consequently, Brussels is the center of the Burundian diaspora in Europe. The neighborhood of Elsene-popularly renamed Matongé-is particularly popular among wealthy Burundians and Rwandian and Congolese business owners like caterers and hair dressers. Burundian organizations, with links to The Netherlands, Germany, Luxembourg, and France, have settled here. Many Burundians in Brussels are highly educated, occupy prestigious positions, and a few Burundians who have two passports are even members of the Burundian government.

Half of the respondents occasionally visited compatriots in Belgium for social, religious, or political ends, or in connection with development aid. They often visited Brussels, attending conferences or meetings with governors, or visiting compatriots. They also maintained contacts with the country of origin from within Belgium. Viviane (female, 50 years old, naturalized) explained the following:

\section{"The first trip after I had my permit was to Brus- sels, to people I knew from Burundi. That was a great event. My husband and I often go there now. There is an ambiance similar to that in Africa, very different from here. Then we feel as if we are back in Burundi."}

Given the importance of Belgium to Burundians, this country also posed a greater threat to some of the respondents. In Belgium, the diaspora was divided. The Hutu and the Tutsi did not mix at all and apart from the ethnic cleavage there were cleavages among the Hutu based primarily on time of arrival: the uncompromising first arrivals and the more open minded newcomers. The various diaspora groups reinforced the antagonisms through mutual positioning as political others [51, page 752/3]. For example, Isabelle (female, 36 years old, temporary residence permit) became very agitated when asked the question whether she ever visits 
the African neighborhood in Brussels: "It wasn't Brussels that brought us here. It's the Dutch who saved us!" She was not the only one to maintain distance from the Burundian community in Belgium. Claudine (female, 28 years old, temporary residence permit) also said she was content to have been allotted a home in a remote place in the north of The Netherlands:

\section{"I prefer to live here. If you are from a country like that, you have experienced so much. I think that you have so much more tranquility over here. You should not have such a busy life right away. It should go slowly. You need to let it develop in your head."}

In sum, transnationalism took a different form in The Netherlands than in Belgium because of the composition of the Burundian migrant population in both countries. The politically active Hutus who fled from Burundi before the 1990s predominantly went to Belgium. They had formed a close-knit, albeit divided community in Belgium, complete with established political, religious, and cultural institutions. Hence, Belgium fulfilled a more central role in the diaspora than The Netherlands. This central position posed a threat to the respondents who wanted to keep their distance from their compatriots. Significant differences between settlement countries have also been found for Moroccan migrants, for example. Many highly-educated Moroccan migrants migrated during and after the colonial period to France, while predominantly lower-educated Moroccan Berbers immigrated at a later time as guest laborers to countries like The Netherlands. Therefore, migrant populations differ between settlement countries because settlement countries take up different positions in relation to the country of origin [52]. The use of the term diaspora contains the risk of detaching a migrant population from the national context in relation to different settlement countries, as if the relationship between settlement countries and countries of origin does not matter [28], [29, page 789], [38, page 232], [45].

\section{Conclusion}

Our findings suggest that the rather "optimistic" assumptions underlying the "transnational turn" $[53,54]$ in migration studies do not apply to the population of Burundian asylum seekers in The Netherlands, which deviates from other populations initially studied with respect to magnitude, duration of stay, and motive for migration. Transnationalism is not self-evident for the victims of the conflicts in Burundi nor is it self-evident for economically deprived Burundians who lack the opportunities to maintain such contacts. Although Burundians live together peacefully in The Netherlands, contact and identification with compatriots either in the country of settlement or elsewhere are not self-evident due to smoldering ethnic and political divisions among Burundians. Furthermore, Burundian transnationalism plays out differently in the Netherlands than in Belgium. The latter plays a more central role in Burundian transnationalism than The Netherlands given its position as former colonizer. Belgium is therefore more attractive to
Burundians who want to be transnationally active and less attractive to Burundians who want to refrain from it. In sum, transnationalism is not self-evident for Burundians; divisions and conflicts in the country of origin continue to influence migrant populations rendering it a heterogeneous population, and transnationalism is shaped differently in the settlement countries of The Netherlands and Belgium.

Our study has been small-scale and exploratory in nature and has only studied transnationalism "from below" [28]. Moreover, it has been limited to the settlement country of The Netherlands and, hence, has not adopted a transnational methodology. In this respect, it is less advanced than "multisited" ethnographic studies that complement the one-sided studies of immigrants in receiving countries with research into the role of those who stay behind in the countries of origin $[55,56]$ and of longitudinal studies where transmigrants are followed for a longer period (as advocated by [41, page 9]).

Nonetheless, our study has shown that migration motives play an important role in transnationalism. Although our research supports Al-Ali et al. [8] finding that asylum seekers are not only transnationally active in a political sense but also in other ways, this does not imply that they are comparable with labor and family migrants in all respects. For asylum seekers, transnationalism is less self-evident, more charged, and more likely to deal with people of the same ethnic or religious background instead of the same country of origin. Neglecting migration motives implies that important differences in the type and intensity of transnationalism are being ignored.

Our conclusion is congruent with the way transnationalism has developed as a research field. The first theories on transnationalism were primarily based on established communities of labor and family migrants [1]. Allegedly, this led to the belief we were entering "a post-national era" [51, page 745], suggesting transnationalism was "everywhere." Subsequently, it has become increasingly clear that transnationalism plays out differently for specific categories of migrants in different contexts and does not contain itself to "home" and "settlement" countries. For example, while the role of nostalgia in creating an imagined homeland and a clear distinction between "home" and "away" are particularly important for adults, future imaginations of "homelands", and the blurring of the distinction between places that "send" and "receive" are more important to children [57]. Furthermore, transnationalism has also been shown to be a highly gendered phenomenon. For instance, apart from the fact that men are overrepresented in public and institutionalized transnational ties while women dominate the caring and kin work in transnational families, men also have a stronger orientation toward the community of origin because they often lose social status in the process of migration, whereas the inverse is true for women $[29,58]$. At the same time, the impact of factors like migration motive, life course, and gender have proven to be highly context-dependent. This means our study has contributed to more recent research showing transnationalism is more multifaceted and complex than assumed at the beginning of the "transnational turn" in migration studies. 


\section{References}

[1] A. Portes, "Introduction: the debates and significance of immigrant transnationalism," Global Networks, vol. 1, no. 3, pp. 181-193, 2001.

[2] A. Portes and M. Zhou, "Should immigrants assimilate?" The Public Interest, vol. 116, pp. 18-33, 1994.

[3] R. C. Smith, Mexican New York: Transnational Lives of New Immigrants, University of California Press, Berkeley, Calif, USA, 2006.

[4] P. Levitt and B. N. Jaworsky, "Transnational migration studies: past developments and future trends," Annual Review of Sociology, vol. 33, pp. 129-156, 2007.

[5] A. Portes, "Conclusion: theoretical convergencies and empirical evidence in the study of immigrant transnationalism," International Migration Review, vol. 37, no. 3, pp. 874-892, 2003.

[6] S. Jansen, "Misplaced masculinities: status loss and the location of gendered subjectivities amongst "non-transnational" Bosnian refugees," Anthropological Theory, vol. 8, no. 2, pp. 181-200, 2008.

[7] E. Morawska, "Immigrant transnationalism and assimilation: a variety of combinations and the analytic strategy it suggests," in Toward Assimilation and Citizenship: Immigrants in Liberal Nation-States, pp. 133-176, Palgrave Macmillan, Hampshire, UK, 2003.

[8] N. Al-Ali, R. Black, and K. Koser, "Refugees and transnationalism: the experience of Bosnians and Eritreans in Europe," Journal of Ethnic and Migration Studies, vol. 27, no. 4, pp. 615634, 2001.

[9] A. Bloch, "Zimbabweans in Britain: transnational activities and capabilities," Journal of Ethnic and Migration Studies, vol. 34, no. 2, pp. 287-305, 2008.

[10] H. Snick, Een huis met vele kamers: Transnationalisme bij Burundese asielmigranten [M.S. thesis], Erasmus Universiteit Rotterdam, Rotterdam, The Netherlands, 2007.

[11] A. De Swaan, "Uitdijende kringen van desidentificatie: gedachten over rwanda (expanding circles of desidentification: thoughts on rwanda)," Amsterdams Sociologisch Tijdschrift, vol. 24, no. 1, pp. 3-23, 1997.

[12] J. R. Bowen, "The myth of global ethnic conflict," Journal of Democracy, vol. 7, no. 4, pp. 3-14, 1996.

[13] P. Verlinden, Rwanda/Burundi: Mensen, Politiek, Economie, Cultuur, Koninklijk Instituut voor de Tropen, Amsterdam, The Netherlands, 1996.

[14] R. M. Kadende-Kaiser and P. Kaiser, "Modern folklore, identity, and political change in burundi," African Studies Review, vol. 40, no. 3, pp. 29-54, 1997.

[15] J. Corduwener, "We weten niets van het binnenland van Afrika," Internationale Samenwerking, vol. 29, no. 2, pp. 3033, 2007.

[16] UNHCR, 2006 Global Trends: Refugees, Asylum-Seekers, Returnees, Internally Displaced and Stateless Persons, The UN Refugee Agency, 2007.

[17] UNHCR/Governments, http://www.Unhcr.org/pages/49e45c0 56.html.

[18] MPI, Data Hub, http://www.Migrationinformation.org/datahub/.

[19] J. De Boom, A. Weltevrede, E. Snel, and G. Engbersen, "Migration and migration policies in the Netherlands 2006," Dutch SOPEMI-Report 2006, Risbo/EUR, 2008.

[20] CBS, Bevolkingsontwikkeling Naar Herkomstgroepering, Asielverzoeken Naar Nationaliteit En Verleende Verblijfsvergunningen Asiel (Demographic Development Per Country of Origin,
Asylum Applications Per Nationality and Per Granted Asylum Applications), 2009.

[21] L. Lucassen, "Is transnationalism compatible with assimilations: examples from western europe since 1850," in Proceedings of the Migrants, Nations and Citizenship, CRASSH, University of Cambridge, July, 2004.

[22] N. Glick-Schiller, "The centrality of ethnography in the study of transnational migration," in American Arrivals: Anthropology Engages the New Immigrant, N. Foner, Ed., School of American Research Press, Santa Fe, NM, USA, 2003.

[23] J. Carling, "The human dynamics of migrant transnationalism," Ethnic and Racial Studies, vol. 31, no. 8, pp. 1452-1477, 2008.

[24] T. De Bruyn and J. Wets, Remittances in the Great Lakes Region, Migration Research Series, IOM, Geneva, Switzerland, 2006.

[25] J. Kusters, R. Plug, J. Schapendonk, and T. Van Naerssen, Een Inventarisatie Van Afrikaanse Migrantenorganisaties in Nederland Betrokken Bij Ontwikkelingssamenwerking, Radboud Universiteit, Nijmegen, The Netherlands, 2006.

[26] N. Al-Ali, R. Black, and K. Koser, "The limits to "transnationalism": Bosnian and Eritrean refugees in Europe as emerging transnational communities," Ethnic and Racial Studies, vol. 24, no. 4, pp. 578-600, 2001.

[27] J. Dahinden, "Contesting transnationalism? Lessons from the study of Albanian migration networks from former Yugoslavia," Global Networks, vol. 5, no. 2, pp. 191-208, 2005.

[28] M. P. Smith and L. Guarnizo, Transnationalism from Below, Transaction Books, New Brunswick, NJ, USA, 1998.

[29] J. Itzigsohn and S. G. Saucedo, "Incorporation, transnationalism, and gender: immigrant incorporation and sociocultural transnationalism," International Migration Review, vol. 36, no. 4, pp. 895-920, 2005.

[30] L. Williams, "Social networks of refugees in the United Kingdom: tradition, tactics and new community spaces," Journal of Ethnic and Migration Studies, vol. 32, no. 5, pp. 865879, 2006.

[31] H. Van Amersfoort, Transnationalisme, Moderne diaspora's En Sociale Cohesie, IMES, Amsterdam, The Netherlands, 2001.

[32] A. Fermin and S. Van der Hijden, "Marokkaanse en turkse overheden en transnationaal Burgerschap," Migrantenstudies, vol. 20, no. 4, pp. 221-237, 2004.

[33] E. Snel, G. Engbersen, and A. Leerkes, “Transnational involvement and social integration," Global Networks: A Journal of Transnational Affairs, vol. 6, no. 3, pp. 285-308, 2006.

[34] S. Turner, "Cyberwars of words: expressing the unspeakable in Burundi's diaspora," Journal of Ethnic and Migration Studies, vol. 34, no. 7, pp. 1161-1180, 2008.

[35] J. Schuster, "Praying for beatrix and mohammed VI," Contrast, vol. 7, no. 39, pp. 5-7, 2000.

[36] H. Haque Khondker, "Bengali-speaking families in Singapore: home, nation and the world," International Migration, vol. 46, no. 4, pp. 177-198, 2008.

[37] L. Kelly, "Bosnian refugees in Britain: questioning community," Sociology, vol. 37, no. 1, pp. 35-49, 2003.

[38] Ö. Wahlbeck, "The concept of diaspora as an analytical tool in the study of refugee communities," Journal of Ethnic and Migration Studies, vol. 28, no. 2, pp. 221-238, 2002.

[39] R. Waldinger and D. Fitzgerald, "Transnationalism in question," American Journal of Sociology, vol. 109, no. 5, pp. 11771195, 2004.

[40] R. Gowrichan, "De duurzaamheid van het transnationalisme: de tweede generatie Hindostanen in Nederland," Migrantenstudies, vol. 20, no. 4, pp. 252-268, 2004. 
[41] S. Huang, B. S. A. Yeoh, and T. Lam, "Asian transnational families in transition: the liminality of simultaneity," International Migration, vol. 46, no. 4, pp. 3-13, 2008.

[42] IOM, Migration and Development: Opportunities and Challenges for Policymakers, International Organization for Migration, Geneva, Switzerland, 2006.

[43] G. Sheffer, Diaspora Politics: At Home Abroad, Cambridge University Press, Cambridge, Mass, USA, 2003.

[44] T. Faist, "Towards transnational studies: world theories, transnationalism and changing institutions," in Proceedings of the IMISCOE-EUI Conference "Diaspora and Transnationalism. Conceptual, Theoretical and Methodological Challenges", European University Institute, Florence, Ky, USA, 2008.

[45] IOM, Engaging Diaspora as Development Partners for Home and Destination Countries, Discussion paper for the Workshop on Migration and Development, Geneva, Switzerland, 2005.

[46] EC, Migration and Development: Some Concrete Orientations, COM, 2005.

[47] OECD, Migration, Remittances and Development, Organization for Economic Co-operation and Development, Paris, France, 2005.

[48] UN, International Migration and Development. Report of the Secretary-General., A/60/871. General Assembly, 16th session, Globalization and nterdependence: International Migration and Development, 2006.

[49] X. Biao, R. Black, M. Collyer, E. Markova, G. Engbersen, and L. Heering, Migration and Development: Causes and Consequences, IMISCOE, 2005, Cluster A2 state of the art working paper.

[50] N. V. Hear and N. N. Sørensen, The Migration-Development Nexus, International Organization for Migration/United Nations, Geneva, Switzerland, 2003.

[51] S. Turner, "The waxing and waning of the political field in Burundi and its diaspora," Ethnic and Racial Studies, vol. 31, no. 4, pp. 742-765, 2008.

[52] R. Patterson, "Transnationalism: diaspora-homeland development," Social Forces, vol. 84, no. 4, pp. 1891-1897, 2006.

[53] P. Levitt and N. N. Sørensen, The Transnational Turn in Migration Studies, Global Commission on International Migration, Geneva, Switzerland, 2004.

[54] T. Faist, "The transnational turn in migration research: perspectives for the study of politics and polity," in Transnational Spaces: Disciplinary Perspectives, M. P. Frykman, Ed., pp. 1145, Malmö University, IMER, Malmö, Sweden, 2004.

[55] G. Marcus, "Ethnography in/of the world system. The emergence of multi-sited ethnography," in Ethnography Through Thick and Thin, G. Marcus, Ed., Princeton University Press, Princeton, NJ, USA, 1995.

[56] V. Mazzucato, "Migrant transnationalism: two-way flows, changing institutions and community development between Ghana and the Netherlands," Economic Sociology, vol. 7, no. 3, pp. 8-16, 2006.

[57] K. Gardner, "Transnationational migration and the study of children: an introduction," Journal of Ethnic and Migration Studies, vol. 38, no. 6, pp. 889-912, 2012.

[58] P. Mascini and M. Van Bochove, "Gender stereotyping in the Dutch asylum procedure: "Independent" men versus "dependent" women," International Migration Review, vol. 43, no. 1, pp. 112-133, 2009. 


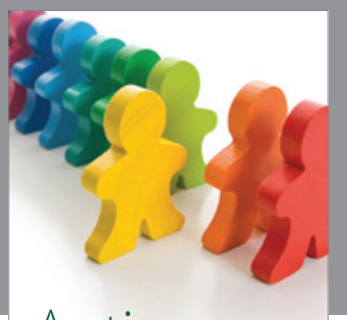

Autism

Research and Treatment
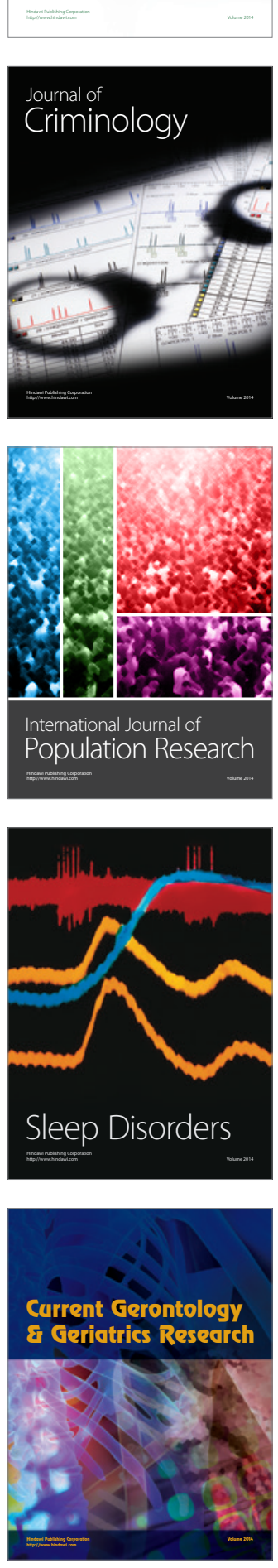
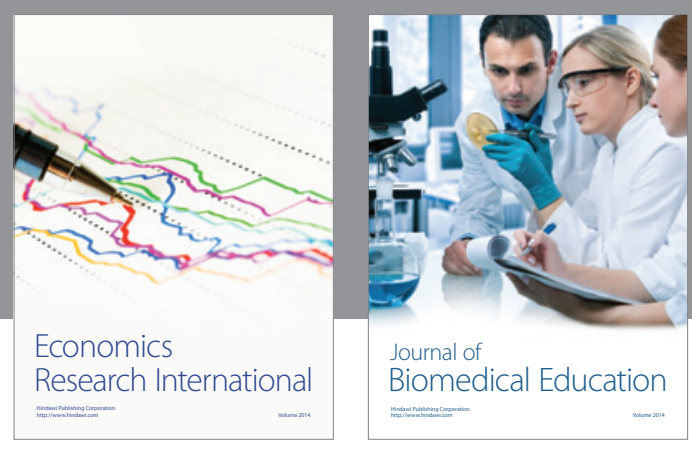

Journal of

Biomedical Education

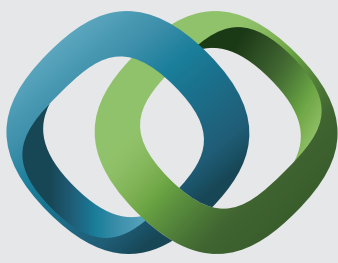

\section{Hindawi}

Submit your manuscripts at

http://www.hindawi.com
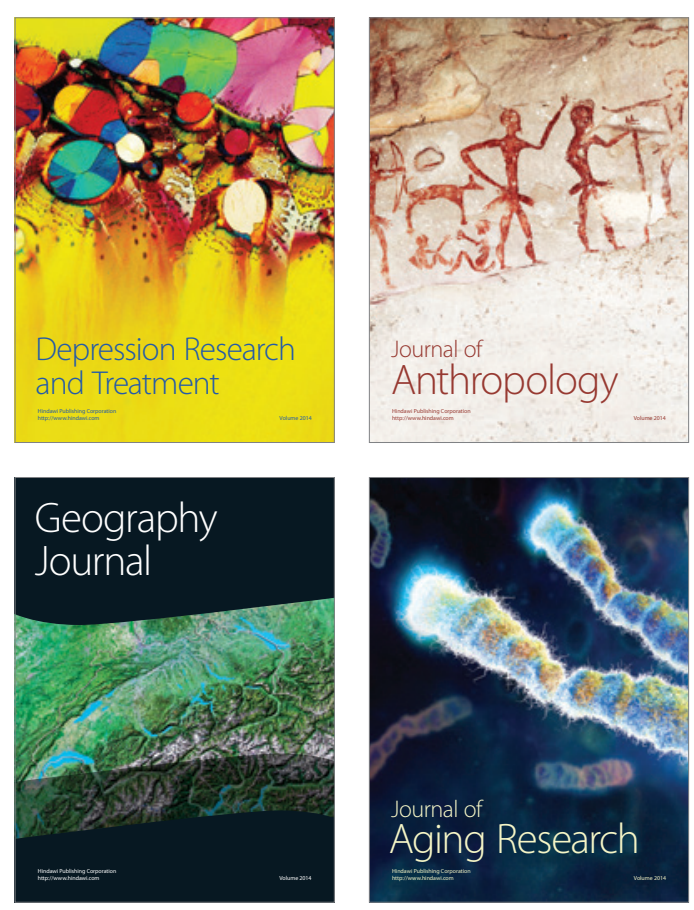

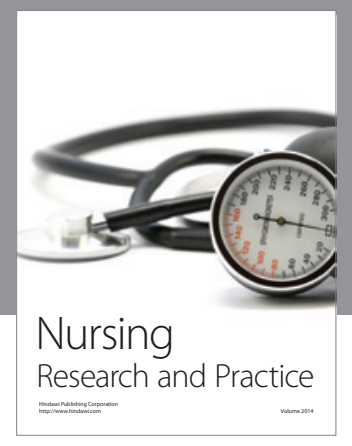

Nursing

Research and Practice

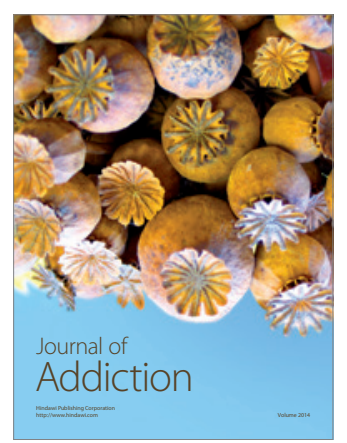

Child Development

Research

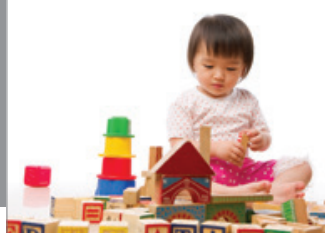

迥
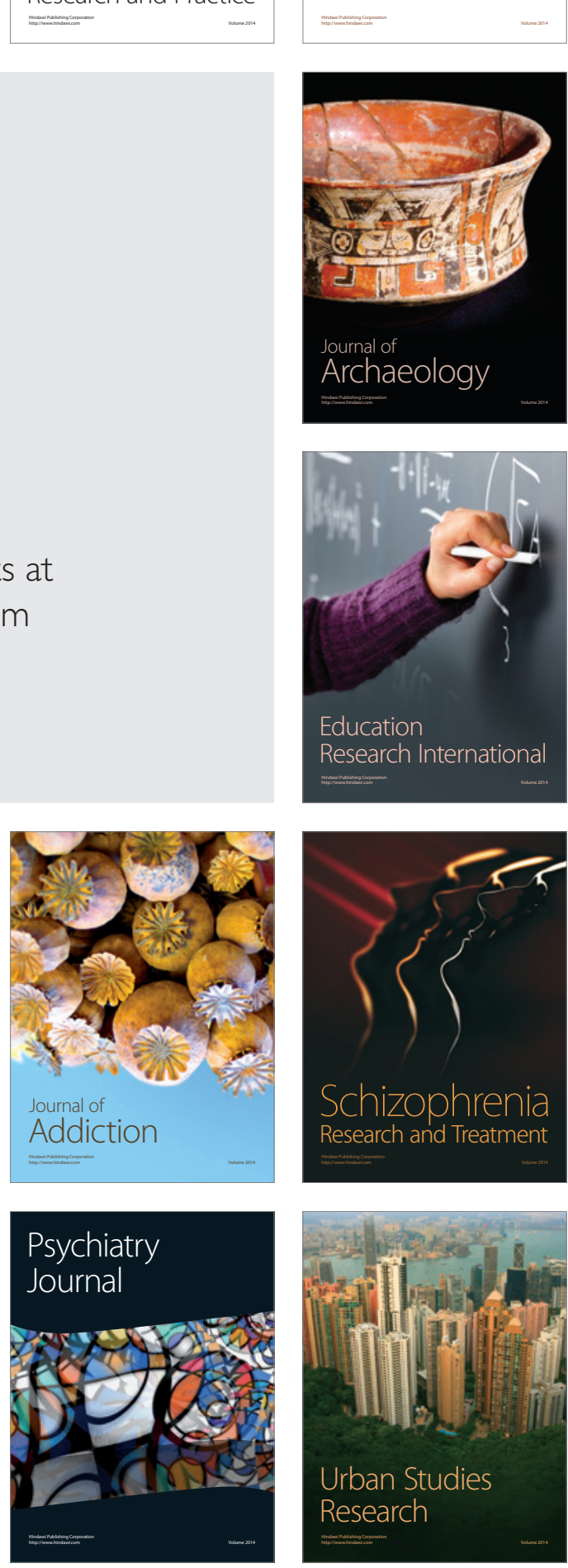